\title{
Small Intestinal Crypt of Lieberkuhn
}

National Cancer Institute

\section{Source}

National Cancer Institute. Small Intestinal Crypt of Lieberkuhn. NCI Thesaurus. Code C33565.

The tube-like glands in the mucosal lining of the small intestines which secrete various enzymes that aid in digestion. 